\title{
AN EFFECT OF SPHAGNUM ON THE GROWTH OF BLACK SPRUCE
}

\author{
BY J. K. MCEWEN ${ }^{1}$
}

\begin{abstract}
$A B S T R A C T$
Black spruce (P. mariana (Mill.) BSP.) grows slowly and reproduces with difficulty on most of the lowland sites where it normally occurs. An examination of the rooting systems of small and large trees indicates that growth was initiated at points substantially below the present ground surface. From the evidence available it is adduced that the growth of sphagnum is responsible for the poor growth and regeneration of the black spruce.
\end{abstract}

\section{INTRODUCTION}

Early in 1964, a series of observations made upon an organic site in Colquhoun Township of the Cochrane District indicated that there had been an irregular, stimulated growth of sphagnum on the area due to a disturbance in the water balance and the species distribution on the site. During 1964-65, more studies were carried out on both immature and mature spruce to determine in more detail the relationship of the sphagnum to tree growth.

\section{Methods}

The Effect of Sphagnum On Dwarf Immature Spruce

This study took place in two areas; on the same site in Colquhoun Township (East Half, Lot 19, Con. 1) that was under study in the preliminary inquiry and on Lots 22, 23, Con. III, Kennedy Township. This latter site is a level peat bed several feet in depth and with very similar vegetation to the Colquhoun area.

In both cases the surface is hummocky, bearing scattered black spruce (Picea mariana (Mill.) BSP) less than 35 years in age. Labrador tea (Ledum groenlandicum (Oeder) ), leatherleaf (Chamaedaphne calyculata (L.) Moench var. angustifolia (Ait.) Rehd. and var. latifolia (Ait.) Fern.), bog rosemary (Andromeda glaucophylla Link), sheep laurel (Kalmia angustifolia L.), bog laurel (Kalmia polifolia Wang.), blueberry (Vaccinium angustifolium Ait.), cranberry (V. Oxycoccos L.), cloudberry (Rubus Chamaemorus L.), pitcher plant (Sarracenia purpurea L.), and cotton grass (Eriophorum sp.) constitute the principal vascular vegetation and Sphagnum, Mnium, Pleurozium schreberi, Cladonia sp., the bryophytic forms. Figure 1 illustrates the irregular nature of the surface of the moss.

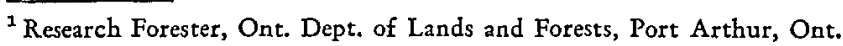


From the Colquhoun and Kennedy areas, a number of stunted spruce were dug and classified as hummock, slope or hollow forms according to their position on the sphagnum hummocks. Approximately 30 specimens in each category were collected in each township.

The vertical root lengths of these stunted trees were measured, using the present moss surface as the dividing line. They were then cut at the surface level and at each 1 inch lower level. The surfaces were sanded and the rings counted, using a binocular microscope (20x) for the purpose. The material was small, some annual rings were apparently fused at certain depths and, even under magnification, precise aging was not possible. Nevertheless, it was felt that the counts quite adequately illustrated the conditions encountered. Table 1 summarizes the measurements which were made.

TABLE 1

Summary of Measurements on Stunted Black Spruce

\begin{tabular}{|c|c|c|c|c|c|}
\hline \multirow[b]{2}{*}{ Township } & \multirow[b]{2}{*}{ No. } & \multicolumn{2}{|c|}{$\begin{array}{l}\text { Vert. root length } \\
\text { (in.) }\end{array}$} & \multicolumn{2}{|c|}{$\begin{array}{l}\text { Depth to Max. Age } \\
\text { (in.) }\end{array}$} \\
\hline & & A ver. & Range & Aver. & Range \\
\hline \multicolumn{6}{|c|}{ Hollows } \\
\hline Kennedy & 31 & 6.5 & $2.5-9.0$ & 0.7 & $0-5$ \\
\hline Colquhoun & 30 & 7.4 & $3.5-13.0$ & 0.9 & $0-3$ \\
\hline \multicolumn{6}{|c|}{ Slopes } \\
\hline Kennedy & 31 & 8.1 & $3.0-15.0$ & 2.5 & $0-7$ \\
\hline Colquhoun & 30 & 12.8 & $6.5-21.0$ & 3.3 & $0.5-10.5$ \\
\hline \multicolumn{6}{|c|}{ Hummocks } \\
\hline Kennedy & 31 & 10.9 & $7.5-14.5$ & 4.4 & $2.0-10.5$ \\
\hline Colquhoun & 29 & 16.7 & $12.0-25.0$ & 5.2 & $2.0-9.0$ \\
\hline
\end{tabular}

The Effect of Sphagnum on Mature Spruce

\section{Horizontal Root Study}

For this study, apparently sound trees representative of the stands in which they, grew, were chosen for root examination. In Evelyn Township, one tree was selected from a meso-oligotrophic ${ }^{2}$ site and one from a eutrophic ${ }^{2}$ site. Over 50 miles from Evelyn Township, 17 trees from oligotrophic ${ }^{2}$ or mesotrophic ${ }^{2}$ sites and four trees from eutrophic sites were selected on four lots in Leitch Township.

On the mesotrophic and oligotrophic sites, the species of vegetation cited above appeared. There were also noted, in varying amounts, creeping snowberry (Gaultheria hispidula (L.) Bigel.), goldthread (Coptis groenlandica

\footnotetext{
Eutrophic - of high nutrient content

Mesotrophic - of medium nutrient content

Oligotrophic - of low nutrient content
} 
(Oeder) Fern.), dwarf birch (Betula sp.), twinflower (Linnaea borealis L.), bunchberry (Cornus canadensis L.), comandra (Geocaulon lividum (Richards.) Fern.), false Solomon's Seal (Smilacina trifolia (L.) Desf.) and the feather mosses (Ptilium crista-castrensis and Hylocomium splendens).

The better quality sites were flushed by runoff from adjacent mineral soil or had mineral soil less than two feet below the ground surface. On these sites such species as red osier (Cornus stolonifera Michx.), mountain ash (Pyrus decora Sarg. var. groenlandica (Schnied.) Fern.), wood horsetail (Equisetum sylvaticum L.), fireweed (Epilobium angustifolium L.), sweet-scented bedstraw (Galium triflorum Michx.), rose (Rosa sp.), raspberry (Rubus sp.) were found in addition to sphagnums and feather mosses.

The horizontal roots of selected trees were severed with a chain saw in a circle about 5 feet in diameter about each stump. The stumps were then removed from the ground and stripped of peaty material. The horizontal roots were severed at the point of contact with the vertical root system, numbered and recorded as living or dead. The cut surfaces were sanded and a count was made of the annual rings for each root and for the tree stump at a point about 8 inches above the moss surface. The records obtained from one stump from a meso-oligotrophic site and from a stump from a eutrophic site are given in Table 2 and are representative of all examined.

All stumps showed mortality in the rooting systems. Stumps from eutrophic sites showed much shallower rooting systems and less mortality of roots than did stumps from mesotrophic or oligotrophic sites. Figures 2 and 3 illustrate the difference in appearance of these roots. Heart rot at stump height

Figure 1. Section through sphagnum hummocks

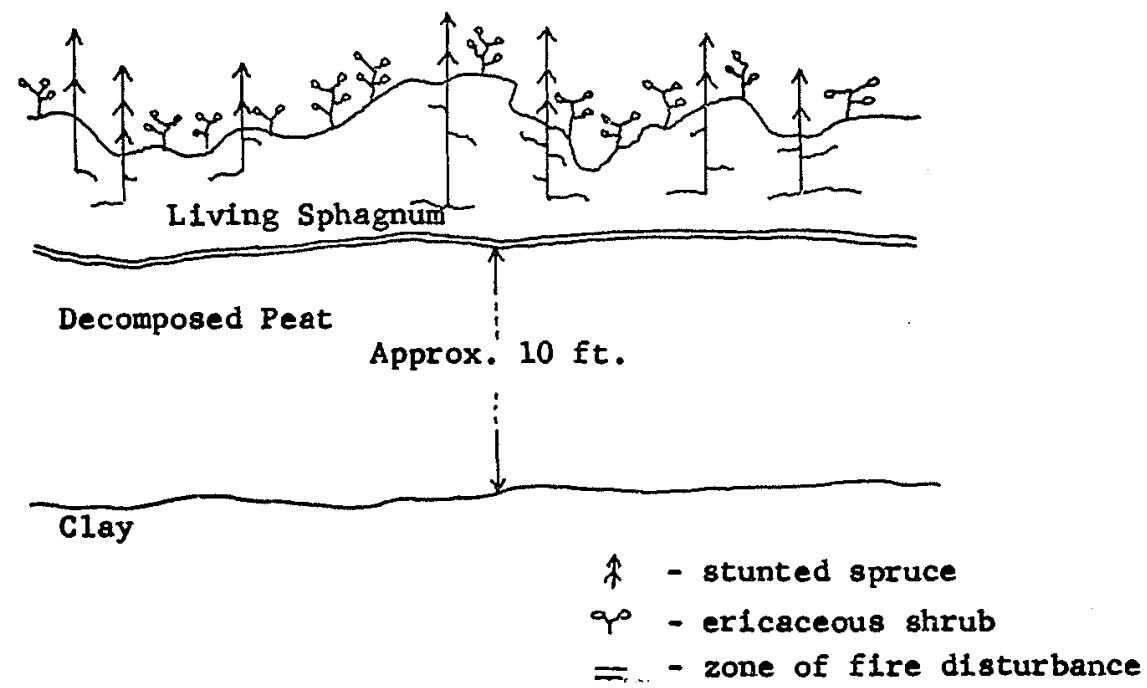




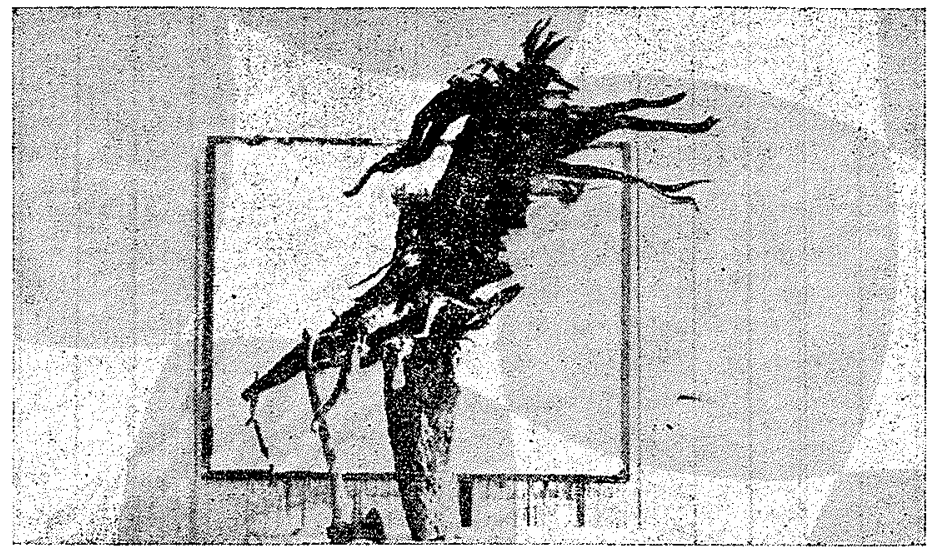

Stump from mesotrophic site.

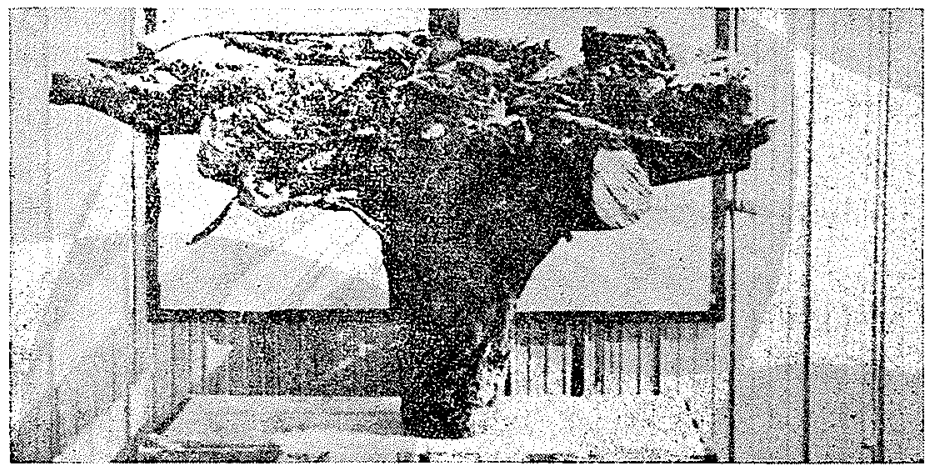

Stump from entrophic site.

(approximately 8 inches above the moss surface) seems to be associated with advanced and extensive rot in the lower portions of the rooting system.

The maximum ring count for horizontal roots on oligotrophic or mesotrophic sites were notably lower than the ring counts at stump height. On eutrophic sites the variation was much less. This can be seen from Table 3 in which the comparative ring counts are recorded for the 23 trees studied. 
TABLE 2

Position, Age and Condition of Horizontal Roots From Two Stumps (measured from lowest point on root)

\begin{tabular}{|c|c|c|c|c|c|}
\hline \multicolumn{3}{|c|}{$\begin{array}{l}\text { Meso-Oligotrophic Site } \\
\text { Stump age - } 140 \text { years }\end{array}$} & \multicolumn{3}{|c|}{$\begin{array}{c}\text { Eutrophic Site } \\
\text { Stump age - } 145 \text { years }\end{array}$} \\
\hline $\begin{array}{c}\text { Height } \\
\text { on root } \\
\text { (in.) }\end{array}$ & Age & Condition & $\begin{array}{c}\text { Height } \\
\text { on root } \\
\text { (in.) }\end{array}$ & Age & Condition \\
\hline $313 / 4$ & 17 & & $131 / 4$ & 48 & \\
\hline $283 / 4$ & 37 & & $113 / 4$ & 59 & \\
\hline $273 / 4$ & 33 & & 11 & 100 & \\
\hline $271 / 2$ & 18 & & $91 / 2$ & 82 & \\
\hline $271 / 2$ & 27 & & $81 / 4$ & 40 & \\
\hline $261 / 2$ & 25 & & 7 & 47 & \\
\hline $243 / 4$ & 39 & & $61 / 2$ & 123 & \\
\hline $241 / 2$ & 16 & & $61 / 2$ & 60 & \\
\hline $241 / 4$ & 38 & & $61 / 2$ & 133 & \\
\hline $231 / 2$ & 28 & & $53 / 4$ & 118 & \\
\hline $221 / 2$ & 59 & & $53 / 4$ & 113 & \\
\hline 22 & 56 & & $51 / 4$ & 59 & \\
\hline $213 / 4$ & 34 & & $41 / 2$ & 72 & \\
\hline $20^{1 / 2}$ & 27 & & $41 / 2$ & 74 & Dead \\
\hline $201 / 4$ & 65 & & $41 / 2$ & 82 & \\
\hline $191 / 4$ & 70 & & & & \\
\hline $183 / 4$ & $-^{1}$ & Dead & & & \\
\hline $151 / 2$ & 55 & Dead & & & \\
\hline $151 / 4$ & 52 & Dead & & & \\
\hline $131 / 2$ & 42 & Dead & & & \\
\hline $121 / 4$ & 33 & Dead & & & \\
\hline 11 & $-^{x}$ & Dead & & & \\
\hline 11 & $-^{1}$ & Dead & & & \\
\hline $101 / 2$ & 28 & Dead & & & \\
\hline 10 & 34 & Dead & & & \\
\hline $83 / 4$ & 14 & Dead & & & \\
\hline $41 / 2$ & 29 & Dead & & & \\
\hline $31 / 4$ & 27 & Dead & & & \\
\hline
\end{tabular}

${ }^{1}$ Too rotten to count. 
FORESTRY CHRONICLE

TABLE 3

COMPaRison of Root and Stump Ages

\begin{tabular}{|c|c|c|c|}
\hline Stump Age & $\begin{array}{c}\text { Oldest } \\
\text { Horizontal } \\
\text { Root }\end{array}$ & Stamp Age & $\begin{array}{c}\text { Oldest } \\
\text { Horizontal } \\
\text { Root }\end{array}$ \\
\hline \multicolumn{4}{|c|}{ Mesotrophic or Oligotrophic Sites } \\
\hline 131 & 80 & 199 & 102 \\
\hline 131 & 86 & 140 & 70 \\
\hline 132 & 103 & 216 & 94 \\
\hline 92 & 54 & 171 & 73 \\
\hline 121 & 67 & 160 (approx.) & 73 \\
\hline 160 & 76 & 180 (approx.) & 90 \\
\hline 143 & 78 & 195 (approx.) & 61 \\
\hline $182+$ & 83 & 171 & 60 \\
\hline 156 & 102 & 241 & 79 \\
\hline \multicolumn{4}{|c|}{ Eutrophic Sites } \\
\hline 145 & 133 & 162 & 146 \\
\hline 134 & 111 & 158 (approx.) & 133 \\
\hline 161 & 153 & & \\
\hline
\end{tabular}

\section{VERTICAL ROOT STUDY}

In order to examine the annual ring development on the vertical portion of the rooting system, the vertical root portion of two mature trees from mesotrophic sites were chosen. These were not too decayed for counting and were cut horizontally into sections. One of the stumps was small enough to be cut on a band saw and the cuts were made at intervals of 2 inches. The other, due to its larger size, had to be cut with a chain saw and the sections, due to the wide saw kerf, had to be somewhat irregular. The records of these counts are shown in Table 4.

TABLE 4

Ring Counts at Measured Depths Below Moss Surface

\begin{tabular}{cccc}
\hline & Tree A & & \multicolumn{2}{c}{ Tree B } \\
\cline { 5 - 5 } $\begin{array}{c}\text { Depth } \\
\text { (in.) }\end{array}$ & $\begin{array}{c}\text { Ring } \\
\text { Count }\end{array}$ & $\begin{array}{c}\text { Depth } \\
\text { (in.) }\end{array}$ & $\begin{array}{c}\text { Ring } \\
\text { Count }\end{array}$ \\
\hline 2 & 131 & $21 / 8$ & 133 \\
4 & 132 & $37 / 8$ & 134 \\
6 & 133 & $55 / 8$ & 135 \\
8 & 136 & $71 / 2$ & 135 \\
10 & 134 & $91 / 4$ & 135 \\
12 & 134 & $113 / 8$ & 127 \\
14 & 104 & $133 / 4$ & 98 \\
16 & 72 & $161 / 8$ & 65 \\
18 & 45 & $181 / 4$ & 54 \\
20 & 40 & $201 / 4$ & 41 \\
\hline
\end{tabular}


From the record above, it seemed that the oldest portions of these trees lay at depths of about 8 or 9 inches below the moss surface.

A vertical cross section of a tree extending from its apex to the lowest portion of its root could be described as a series of concentric tubes (annual rings) with the innermost tube representing the oldest portion of the tree. Figure 4A represents a stylized version of such a structure.

Figure 4. Stylized representation of annual rings in tree

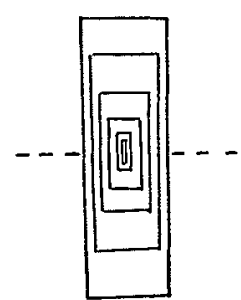

A

\section{Moss Surface}

\section{Eutrophic Site}

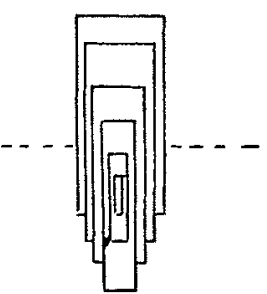

When vertical cuts were made through the sections counted in Table 4 above it was found that it was the marginal rings at the lower portions of the root that were missing. Figure $4 \mathrm{~B}$ represents in stylized form what was seen. This may be due to the death of the cambium as the lower roots die. At any rate, it was possible to calculate the age-depth relationship for the two trees with greater accuracy (Table 5).

TABLE 5

Adjusted Age Measurements at Measured Depths

\begin{tabular}{cccc}
\hline & Tree A & & \multicolumn{2}{c}{ Tree B } \\
\cline { 1 - 1 } $\begin{array}{c}\text { Depth } \\
\text { (in.) }\end{array}$ & Age & $\begin{array}{c}\text { Depth } \\
\text { (in.) }\end{array}$ & Age \\
\hline 2 & 131 & $21 / 8$ & 133 \\
4 & 132 & $37 / 8$ & 134 \\
6 & 133 & $55 / 8$ & 135 \\
8 & 136 & $71 / 2$ & 135 \\
10 & 135 & $91 / 4$ & 141 \\
12 & 135 & $113 / 8$ & 141 \\
14 & 134 & $133 / 4$ & 141 \\
16 & 129 & $161 / 8$ & 139 \\
18 & 128 & $181 / 4$ & 139 \\
20 & 128 & $201 / 4$ & 138 \\
\hline
\end{tabular}




\section{Discussion}

During the preliminary studies in 1964 , on the basis of a few root systems examined, the conclusion was reached that sphagnum was growing as a result of stand disturbance and that its growth was overwhelming the spruce regeneration upon the area.

In this report, the root study of stunted immature spruce has been extended to 182 trees selected at random on similar areas in two townships 30 miles apart. Once again it has been found that the oldest portion of the tree frequently lies several inches below the surface of the moss.

There is the possibility that seeds have penetrated the sphagnum for some distance before germinating. Also the opinion is frequently voiced that trees tend to sink into the sphagnum.

Unquestionably, some of the fine seeds do penetrate between the sphagnum stems and the moisture content of the sphagnum could lead to germination. The spruce seedling is, however, a comparatively frail object and it is felt that survival would not be possible if the seed began to germinate more than an inch below the surface. On wet, acid sites there is, as well, an osmotic, killing effect on the seed, as has been shown by Rubtsov (1959) in experiments with Scots pine (Pinus sylvestris L.).

The stunted spruce which were examined ranged in length (stem plus vertical root portion) from 17 to 43 inches. With such light material it could be anticipated that there would be little or no sinking or that, if sinking occurred, the amount of it might vary directly with the size of the material. This was not the case.

If we hypothesize that the central point for that portion of the stem-root of maximum age was initially the starting point for the seedling, we find that this point now occurs at any distance between the moss surface and a depth of 10.5 inches. The two spruces possessing the longest aerial portions (33 inches and 30 inches) had roots only 21/2 inches and 6 inches long respectively.

Depth of rooting varied greatly. The depth could be anticipated with a moderate degree of accuracy by simply noting the depth of sphagnum mounds and the position relative to them in which the dwarfed tree grew.

If sinking actually occurred, one would also anticipate that there would be a greater settling in the vicinity of the stem and that the horizontal root extremities, being flexible and fine, would be at higher levels. Such a structure, which would be somewhat like an inverted, open umbrella, was not found.

All observations support the contention that it is the upward growth of sphagnum rather than the sinkage of seeds or trees that leads to the deeper rooting. The very accumulation of organic remains on these lands is evidence of this growth. Such authorities as Dansereau and Segadas 4 Vianna (1952) on this continent, Fraser (1933) in the United Kingdom; Sjors (1948) in Sweden, Heikurainen (1960) in Finland and Valk (1959) in Russia have described it.

Since sphagnum attains its optimum growth under conditions of high moisture and half-light, the sphagnum mounds develop according to the location of trees, shrubs and ericaceous plants on the area.

The effect of the inundation of the spruce by wet sphagnum is a retardation 
or cessation in growth of the trees. Either new roots form or the lower branches of the tree become converted to roots. LeBarron (1945) reported on sphagnum effects on the rooting of small black spruce.

On the roots of the mature spruce that were examined, the later stages of this paludification were seen. On the eutrophic sites, the horizontal roots show ring counts which are not too different from the tree age as shown by stump count. In these cases, the horizontal roots are confined to a relatively shallow and flat horizon. Even here there is death of some of the roots at the lowest portion of the trees. On mesotrophic or oligotrophic sites, the horizontal roots extend through a much deeper rooting zone. The individual roots are much smaller and with fewer rings. With the increased depth of growing sphagnum, conditions become wetter and there is a much greater vertical extension of the zone of dead roots at the base of the rooting system.

The principles of paludification have been clearly demonstrated and accepted by numerous authorities across the northern hemisphere. The present material is intended to show that the same forces are at work in Northern Ontario and for this purpose the data are considered adequate.

There are certain techniques which, used in conjunction with logging, might prevent the deterioration of the site and of the forest (McEwen, 1964). If these are delayed, more rigorous treatments might restore the sites to their original, or higher, productivity.

\section{REFERENCES}

DANSEREAU, P. and F. SEGADAS-VIANNA. 1952. Ecological study of the peat bogs of Eastern North America. Canadian Journal of Botany, Vol. 30.

FRASER, G. K. 1933. Studies of certain Scottish moorlands in relation to tree growth. Forestry Commission, United Kingdom, Bull. 15.

HEIKURAINEN, L. 1960. Metsa ojitus ja sen perusteet (In Finnish). WSOY, Porvoo-Helsinki.

LEBARRON, RUSSELL K. 1945. Adjustment of black spruce root systems to increasing depth of peat. Ecol. 26.

McEWEN, J. G. K. 1964. European peatland literature and its possible application in Northern Ontario. Ont. Dept. of Lands and Forests Res. Inf. Paper 29.

RUBTSOV, V. G. 1959. Osushitel 'naya melioratsiya kak mera obespecheniya lecovozobnovleniya (in Russian) Vol. 49. Trudi Instituta Lesa, Akademiya Nauk, SSSR.

SJORS, H. 1948. Myrvegetation i Bergslagen (in Swedish with English summary) Acta Phytogeographica Suecica, Uppsala.

VALK, U. 1959. O leso- e sel'skokhozyaistvennykh problemakh ispol'zovaniya bezlesnykh verkhovykh bolot v Estonii (in Russian) Vol. 49 Trudi Instituta Lesa, Akademiya Nauk, SSSR. 